Article

\title{
Does Chinese Inward Foreign Direct Investment Improve the Productivity of Domestic Firms? Horizontal Linkages and Absorptive Capacities: Firm-Level Evidence from Ethiopia
}

\author{
Engidaw Sisay Negash $₫$, Wenjie Zhu, Yangyang Lu and Zhikai Wang * \\ School of Economics, Zhejiang University, Hangzhou 310027, China; 11601038@zju.edu.cn (E.S.N.); \\ zwj@zju.edu.cn (W.Z.); knerlyy@126.com (Y.L.) \\ * Correspondence: wangzhikai@zju.edu.cn
}

Received: 22 March 2020; Accepted: 2 April 2020; Published: 9 April 2020

\begin{abstract}
Publicized as a global call for action in 2015, the United Nations General Assembly (UNGA) has forwarded an agenda of resolutions to achieve the goals of sustainable development by 2030 (SDGs). Due to the specific challenges of funding gaps and the lack of advanced technology, the majority of Sub-Saharan African (SSA) countries are still behind the standard of world development. Since foreign direct investment (FDI) has the potential to bring much-needed capital and efficient technology, FDI has often been considered as a vigorous source of development, even for sustainable development for under-developing economies experienced today. Conspicuously, Chinese outward FDI (OFDI) into SSA has seen a strong upward trend in the 21st Century, after China proclaimed its "go global" strategy. Ethiopia is one of the favored destinations of the trend of Chinese OFDI, which also substantially continues through the SSA region. The hosting economy of Ethiopia expected that Chinese inward FDI comes with capital, efficient technology, and knowledge to contribute innovations through directly improving productivity and competitiveness via technological diffusion to domestic industries and eventually for sustainable development. Against this backdrop, this study utilizes firm-level panel datasets from Ethiopia to address the following couple of research questions. The first question is: are there any productivity differences between the establishment of Chinese-affiliated and domestic firms in the manufacturing industry in Ethiopia? The second is, does the presence of Chinese-affiliated firms provide productivity spillovers for domestic firms in the same industry level for socio-economic development? The investigation was carried out using 2554 manufacturing firm census data, from which $15.04 \%$ were Chinese firms operating in Ethiopia. We used the ordinary least squares (OLS) and generalized-method-of-moments (GMM) two-step approaches for estimations. Our findings revealed that, generally, Chinese firms were more productive than local firms and their presence can bring positive potential productivity spillover effects for domestic firms. Specifically, we found that local firms have gained significant positive spillovers when they had a high absorptive capacity, whereas low-absorptive capacity firms suffered negative spillovers. We also found that non-exporting domestic firms experience significant positive spillovers from the presence of Chinese firms.
\end{abstract}

Keywords: SDGs; OFDI; productivity spillovers; absorptive capacity; foreign and domestic firms 


\section{Introduction}

Announced as a global paradigm call for action in 2015, the United Nations General Assembly (UNGA) has forwarded an agenda of resolutions to achieve the goals of sustainable development by 2030 (SDGs) [1]. However, before issuing the SDGs of the Agenda in 2015, the United Nations Conference on Trade and Development (UNCTAD) publicized in 2014 that, for realizing the SDGs in 2030, developing countries have been facing an estimated cost of 2.5 trillion USD in funding gaps annually [2]. Indeed, in the modern day, foreign direct investment (FDI) has often been considered as an external trigger source to close the funding gaps for development and even further for sustainable development; among the central goals in the contemporary world is the achievement of SDGs. Globally, governments, policy makers, corporations, and the scientific community are determining that FDI is among the factors for transforming strategic decision-making to achieve the SDGs [3]. Intensely targeting sustainable development has crucial drawbacks for developing countries, and FDI can bring about sustainable socio-economic development for resource-poor countries [4]. Moreover, the UNCTAD has also promoted FDI as being amongst the potential drivers for sustainable development and the safest type of investment for today's developing economies [5].

Against this backdrop, policymakers of developing and transitioning countries have striven to attract FDI to their economies, spending significant effort by providing very generous incentive channels like tax holidays, duty-free (regulatory exemptions), and others [6,7]. Policymakers have also been expected to benefit from FDI, since it brings much-needed financial capital, efficient technology, and managerial expertise that could improve the productivity of local firms in the form of spillover effects in particular and sustainable wealth in general [8,9]. Particularly, the capital injected into the local economy would improve investments to achieve economic take-off, and more job opportunities would be created; hence, the economy of the country would become improved and would be much more competitive in terms of socio-economic development [10]. Moreover, foreign investors usually come with new ideas and efficient technologies that would help in innovations in domestic economies' sustainable improvement [7]. Given this, they could further become potentially miraculous alternative sources of productivity improvement and might help the hosting countries' local firms catch up to new foreign technology frontiers, leading to overall economic maturity $[9,10]$. With the policy priority and a palpable attention by governments in attempting to attract high FDI, determining whether there is a positive outcome of productivity spillovers or externalities from FDI has been brought up as an influential and relevant topic in a vast range of empirical studies.

The basic assumption underlying the presence of FDI spillovers is that foreign-origin firms are technologically efficient, and those spillovers are transmitted through their connections with local firms, which could offer opportunities that lead to the improvement of productivity development in the hosting economies $[6,7,11]$. Strategically, there are several well-defined standard mechanisms through such spillovers that could be realized by foreign-origin invested firms with respect to local-owned firms. Intra-sector or horizontal spillovers are to be expected from managerial expertise, as well as technology and knowledge skills used by foreign-embedded firms, being transmitted to competing firms within the same industry sector [12]. Inter-sector or vertical spillovers are usually transferred by the supply chain from foreign intermediate material suppliers, to local producers or foreign firms, and to local input suppliers in various stages of activities [10,13,14].

In the context of developing countries, most recent empirical literature reported no evidence of the intra-sector or horizontal spillovers, and highlighted vertical or inter-sector spillovers in the form of backward linkages from foreign-invested firms to local suppliers as the major sources of productivity spillover effects $[7,9,13-15]$. Their findings also argued that the types of foreign investors, which could be either wholly foreign-owned or joint-venture firms, matter for the magnitude of spillovers $[7,9,16]$. Overall, however, as the inconclusiveness in the nature of empirical studies and the extent of FDI spillovers were highlighted in the literature reviews in papers by $[17,18]$, conclusions that the varied evidence largely depends on the approach of the methodologies applied, the type of dataset incorporated, and the heterogeneity of the individual country context could be drawn. 
In the view of $[7,19]$, the literature on the FDI spillover context in developing economies indicates that productivity spillovers and productivity transfers are different, albeit linked, ideas, which must be treated with empirical studies. On the other hand, authors in $[7,14,16]$ criticized the existing literature, giving special emphasis to the externalities of the FDI rather than identifying the direct impacts of linkages among foreign and local firms. Based on the above premises, the current study's overarching objective was to investigate whether Chinese (foreign) (we use "Chinese" and "foreign" interchangeably throughout the paper) manufacturing firms' presence in Ethiopia can bring about productivity spillovers and efficiency levels at the same level as local manufacturing Ethiopian firms (hereafter "local" or "domestic"). Particularly, the study aims to achieve the following: (1) investigate the horizontal linkages among foreign and local firms that exhibit the productivity levels that lead to the improvement of the country's economy; (2) examine the productivity of the local firms, and whether or not they are associated with the presence of foreign firms in horizontal spillovers; (3) show that these effects could be consistent with the presence of intra-industry technology spillovers; (4) examine whether productivity stemming from horizontal spillovers differs from local firm characteristics (absorptive capacities).

This study is limited to a particular Chinese inward FDI (IFDI) in the manufacturing sector in Ethiopia for the following reasons. The first reason for this is that Ethiopia has received a significant amount of Chinese IFDI in the manufacturing sector and was placed among the top six hosting countries in Sub-Saharan Africa (SSA) in 2017 ((majority of Chinese outward FDI (OFDI) in SSA has concentrated on South Africa, Congo, Zambia, Nigeria, Angola, Ethiopia, Zimbabwe, Ghana, Kenya, Tanzania, Sudan, and Mauritius). Accordingly, since 2012, Chinese IFDI in Ethiopia has become by far the prime source of external investment, outpacing the traditional investor of the United States [20]. In addition, for more than a decade, Chinese investors have been the dominant source of development projects in Ethiopia; hence, in 2018, around 1239 Chinese projects were registered by the Ethiopian Investment commission (EIC), among which $70 \%$ were concentrated in the manufacturing sector [21]. In addition, due to the data limitations of other countries and the heterogeneous nature and diversity of Chinese investment (for example, in some countries, focusing on mining, oil, and natural gas) in SSA, we could not include other countries in our study. Consequently, theoretical arguments suggested that FDI flows into developing countries such as Ethiopia have an imperative for sustainable development through improving industrialization in the manufacturing sector [22]. Thus, Ethiopia as a globalization perspective and a strong economic integration with China as well as the significance of Chinese IFDI for Ethiopian manufacturing growth, support for socio-economic development remains uncovered on the current empirical investigation. The second reason is that medium and small private Chinese firms have become the leading investors in the Ethiopian manufacturing sector, so there is uncertainty about their impact on the Ethiopian economies, i.e., whether productivity spillover impacts have been positive or negative, especially for local firms. However, the positive spillover effects of OFDI on domestic firm innovation performance cannot be taken for granted [23].

Third, to the best of our knowledge, to date this sectoral level analysis would be the first study utilizing a large sample of datasets of manufacturing firms to report a detailed investigation of Chinese IFDI spillover effects on Ethiopian firm productivity. Therefore, an investigation of a panel dataset from a specifically designed census of 2554 manufacturing firms that are Chinese-affiliated and local and at the same industry level is worthwhile. The census dataset covers only firms from the manufacturing industry, which basically employs 10 or more persons and utilizes a power-driven machine industry. The dataset includes detailed information on the establishment of firm ownership structure, equity participation, employment output, assets, wages, firm location, input costs, and other information. We assumed that this investigation would allow us to directly identify horizontal linkages and productivity transfers among foreign and local firms, using a two-stage econometric approach. In the first stage, we examined the productivity, and we then estimated the relationship between productivity and direct spillovers from Chinese IFDI based on local firm characteristics. 
Our main findings are summarized as follows. We found that Chinese firms were significantly more productive than local firms, indicating that there are positive and direct productivity benefits from Chinese IFDI in local economy development. Regarding the spillover effects, we found that IFDI has diverse spillover effects on the local firms' productivity depending on their individual characteristics. Particularly, our findings show that when local firms have a high absorptive capacity (a small technology gap with respect to foreign investment), they had positive productivity spillovers, whereas low absorptive capacity firms suffered negative spillover effects. We also found that non-exporting and small domestic firms had positive productivity spillovers, while skilled labor did not encourage indirect productivity.

Overall, the current study may provide the following marginal contributions to the emerging literature. First, existing empirical literature for the Ethiopian context has been uncovered to show a broad picture that productivity spillovers from Chinese-owned firms diffused to local firms either in vertical or horizontal, or positive or negative, effects. Hence, our study can be considered as the first cohort of empirical analysis that quantitatively estimates the impact of Chinese IFDI on Ethiopian manufacturing firm productivity spillovers. Second, by utilizing a rich panel data source, including a significant number of firms' recently available data across the local and Chinese manufacturing firm industry, we provide strong and thorough econometric empirical findings for the issue. Finally, we believe our empirical findings could make a considerable contribution to the existing literature for both policymakers and scientists. The rest of the study is structured as follows. Section 2 is a literature review, Section 3 details our empirical approach and presents data, Section 4 reports empirical estimations, and conclusions are reported in Section 5.

\section{Literature Review}

\subsection{Productivity Spillovers from FDI}

Countless studies have argued that government intervention to attract foreign-origin investors improves productivity spillovers, competitiveness, and positive externalities for local economies. Technology and productivity externalities can occur from FDI through different channels (see $[7,9,15,24]$ for brief overviews of various mechanisms). Horizontal spillovers within the same sectors might arise when employees move from foreign-origin firms to local firms, which could bring about knowledge absorbed from the previous companies [11,25]. Similarly, domestically owned firms may perceive that foreign firms operating on the same industry level can copy their existing technologies $[7,26]$. However, it is commonly assumed that such horizontal level externalities in this situation are unlikely to occur. Within similar sectors, foreign-owned firms compete with local firms, so they all have privileges to protect their embodied technologies and knowledge leaking from their direct local competitors [14]. Indeed, there is a significant body of existing empirical studies that have been incapable of finding vigorous evidence that productivity improvements can accrue for local firms through intra-industry spillovers [14,24,25,27-29], nor has there been strong evidence of horizontal spillovers. Wang and Gao [30] explored 40 years of China's OFDI development; despite generally positive effects, the large-scale and unstable OFDI activities have alarmed Chinese policymakers. On the other hand, both developed and developing host countries have demonstrated their concern over national security and the misbehavior of some Chinese overseas companies.

Spillovers among some sectors could be more expected. For instance, spillovers with vertical linkages might be desirable, when the productivity obtained exceeds that internalized through deliberate arrangements between local and foreign-owned firms [7,31]. In the same way, backward spillovers may occur if local firms experience more productivity improvements due to the increase in foreign-owned firms in the downstream level of sectors. These kinds of spillovers are mostly expected to occur when local firms have a source of input from foreign firms that could help improve productivity $[7,11]$. This could happen through several mechanisms that are most likely when planned knowledge transfers from foreign-owned firms to local input supplier firms [7]. It is also probable 
that firms that have no direct link to foreign-owned firms in the downstream may experience more productivity improvements. This might occur in cases where local suppliers have more incentives to increase the worth of their supplying inputs or to improve the efficiency they have provided with which they can increase competition to foreign customers, or in cases where they have large-scale economies that show a greater demand for locally produced intermediates $[7,9,32]$. By its very nature, the direct spillovers by linkages and the indirect spillovers in the nature of externalities are both very likely $[6,31,33]$.

\subsection{Efficiency Spillovers from FDI}

Foreign firms might have better efficiency techniques and other special "spillover" effects not only on local direct competitors (horizontal spillovers) but also on the upstream and downstream indirect competitors of domestic firms (vertical spillovers) $[7,11,15,25,34]$. Efficiency spillovers broadly include the transfer of production methods, managerial practices, marketing promotion techniques, or any other important knowledge that embodies a product or service that can occur through numerous channels [35]. Domestic firms may also learn to replicate the new process or advance the quality of their products and marketing activities through observation or interaction with foreign experts and through local employees working in foreign firms [7,11]. In addition, domestic firms might also have advantages based on new professional services, such as suppliers of inputs, due to a foreign-owned firm entry. On the other hand, foreign firms could act as catalysts for local suppliers to advance the quality or efficiency of time by demanding a higher standard [36]. However, foreign firms could have an adverse effect on the output of domestic firms' efficiency if they crowd out their market or their skilled human resources.

\subsection{Determinants and Impact of Chinese OFDI in Africa}

Theoretically, FDI has been considered as an essential instrument for sustainable economic growth and reducing poverty in developing counties. This is because FDI is one of the mechanisms of foreign capital inflows and it is used to boost the manufacturing industry and trade structure for global convergence. This part of the literature summarizes the determinants and impacts of Chinese OFDI in Africa. Several studies have focused on the Chinese OFDI impact on African developing economies. For example, in [37], the authors examined the impacts of China's activities in SSA countries with a particular focus on economic growth performance in the region. The study used a simple Solow model growth approach over the period 1991-2010. They found that SSA economies exporting natural resources to China positively benefited in terms of foreign trade effects. On the other hand, Chinese OFDI flows in SSA were not shown to have a positive or significant effect on SSA growth. The authors in [38] investigated the main drivers for the rise of Chinese investment in Africa. The authors stated that Chinese OFDI was predominantly attracted by the largest endowment of natural resources and poor institutional environment in the host countries. Factors that attract Chinese OFDI to Africa reported in [39] include natural resource-seeking investment, the risk-free factor, a large market opportunity, the intensity of trade volume, and a large amount of China's contracted projects. It was concluded in $[40,41]$ that raw material resource endowment and market opportunity were major driving factors of Chinese OFDI in African countries. The authors also indicated the motivational factors that attracted a higher number of Chinese economic contract projects to cooperate with Africa. Liu et al. [42] delved into how cultural vastness and dimensions justify China's OFDI spatial diversity. The authors argued that cultural distance had a U-shaped (curvilinear) association with the determinants of China's OFDI. Chen et al. [43] also made investigations from the perspective of the diversities among countries of Chinese OFDI and the industrial upgrading, and the findings show that China gained positive impacts from the industrial upgrading from OFDI in the developed countries and emerging markets in the form of a reverse technology spillover. 
Concerning the benefits of African countries from Chinese investment, the substantial increase of Chinese OFDI in SSA could have negative or positive consequences for SSA countries. The authors in [44] investigated the effect and contribution of Chinese OFDI on SSA countries' growth by utilizing the basic Solow growth accounting model. Their econometric findings indicated that a significant percentage of growth attributed to Chinese OFDI flows to the region was accelerated only in some African countries during the periods before and after the recent financial crisis. The authors in [45] examined the quantitative impact and the direction of China's FDI flow with respect to the growth in Africa between 2003 and 2012 using 20 sampled SSA countries. The study found that an increasing Chinese FDI in Africa was significantly improved in Africa's economic growth. This view was opposed by the report of [46], who employed an accounting growth approach to estimate the effect of Chinese OFDI on African economic growth. It was also argued in [37] that Chinese outward investment in Africa had no significant effect on African economic growth.

\section{The Theoretical Models}

\subsection{Production Function Estimation}

In our analysis, in the first step we estimated the productivity of each firm included in the sample. To do this, the common approach was estimating the production function (PF) and utilizing the estimated results to back out a specific firm measure of productivity. The ordinary least squares (OLS) estimation of the PF needs to have inputs determined independently in the firm efficiency level. This type of assumption is inappropriate in most situations because it could be highly likely that firms' input selections would be correlated with the shocks of unobserved productivity.

If a firm made a variable input selection based on the productivity shocks on that specific firm, but not the observers of the econometrician, this could lead to bias in the OLS evaluations of the estimated coefficients on this input in the PF. For instance, if firms exert higher productivity such that firms would decide to hire more labor, the estimations may show an upward bias in the coefficient on that variable if the productivity cannot be controlled. On the other hand, labor decisions can be counter-cyclical, with more productive firms employing very few labor inputs per unit of capita, which could lead to a downward bias in the OLS estimation coefficient of the labor inputs. This is in line with the theoretical assumption that, when a firm becomes more productive, it becomes more capital-intensive $[7,10]$. The estimation coefficient of the capital would also be biased because of the simultaneity of the variables. In both assumptions, the bias could be run in either direction.

Therefore, semi-parametric methods that are used for some of the indispensible decision-making process in the firms have become a better way to circumvent these concerns. The most common applicable approaches can be found in [7,31,47-49]. Using the set of assumptions about the firms' behavior in relation to how the productivity changes over time and the choices of timing inputs, these methods can correct the endogeneity problems between the unobserved productivity and variable inputs. Here, we followed [48] on the modification version of the [47] model. In addition, we investigated the models in $[50,51]$ with respect to the system of the generalized-method-of-moments (GMM) context, which can be more efficient than the OLS approach. Based on the standard Cobb-Douglas approach we assumed the following PF:

$$
y_{i t}=\beta_{l} L_{i t}+\beta_{k} K_{i t}+\S_{i t}+\varepsilon_{i t}
$$

where $y_{i t}$ is the log value of output, $l_{i t}$ is the log of labour input, $k_{i t}$ is the log of the capital input, $\S_{i t}$ is the unobserved productivity, and $\varepsilon_{i t}$ is the random error term or an unanticipated shock. As in $[7,47,49]$, we assumed that productivity changes according to

$$
E\left(\S_{i t} \mid \S_{i t-1}, \S_{i t-2}, \ldots, \S_{i 1}\right)=E\left(\S_{i t} \mid l_{i t-1}\right)=E\left(\S_{i t} \mid \S_{i t-1}\right), \quad t=2,3, \ldots, T
$$


where $l_{i t-1}$ denotes the information at time $t-1$ and includes the realizations of the past productivity of information sets. In other arguments, the expectations of the firms' future productivity would depend on only the past period of productivity. We assumed that the investment that was capital stock $k_{i t}$ was selected at the time of $t-1$. This assumption was consistent with $[7,47,49]$, showing that capital accumulations form by the following process:

$$
k_{i t}=(1-\delta) k_{i t-1}+\dot{\mathrm{i}}_{i t-1}
$$

where it $_{-1}$ is represented by the investment lag. In addition to our accordance with [7,47], we assumed that labor input can be selected simultaneously so that productivity can be realized. An implication of these assumptions regarding the timing of input choices and the evolution of productivity is that:

$$
\S_{i t}=f\left(k_{i t}, \dot{i}_{i t}\right)
$$

Assuming that $E\left(\varepsilon_{i t} \mid k_{i t}, \dot{i}_{i t}\right)=0$, then substituting for $\S_{i t}$, Equation (1) can be described in the following form:

$$
y_{i t}=\beta_{l} l_{i t}+\beta_{k} k_{i t}+f\left(k_{i t}, \dot{i}_{i t}\right)+\varepsilon_{i t}, \quad t=1,2, \ldots, T
$$

The parameters of $\beta_{l}$ and $\beta_{k}$ would not separately identify, the former due to the collinearity problem in productivity and labor $[7,48]$ and the latter because of the presence of $k_{i t}$ in $f($.$) . Turning to$ the underlying productivity evolution process assumption described in Equation (2), we describe the innovation in the following form:

$$
w_{i t}=\S_{i t}-E\left(\S_{i t} \mid \S_{i t-1}\right)
$$

Combined together with Equation (4), which infers that $\S_{i t-1}=g\left(k_{i-1}, \dot{i}_{i t-1}\right)$, and after several estimations, Equation (6) can be re-written as follows:

$$
\S_{i t}=f\left[g\left(k_{i t-1}, \dot{\mathrm{i}}_{i t-1}\right)\right]+w_{i t}
$$

Substituting into Equation (1) provides us with a second equation that is used to easily identify the interest of the two parameters $\beta_{l}$ and $\beta_{k}$ :

$$
y_{i t}=\beta_{l} l_{i t}+\beta_{k} K_{i t}+f\left[g\left(k_{i t-1}, \dot{1}_{i t-1}\right)\right]+U_{i t}, \quad t=2,3, \ldots, T
$$

where $U_{i t}=w_{i t}+\varepsilon_{i t}$. A set of an appropriate moment of restrictions appears from the assumption of the underlying development of productivity and the choice of timing inputs. Equation (6) infers that innovation would be independent of the set of information at time $t-1$, i.e., it-1. Since $k_{i t}$ is controlled at period $t-1$, it would be uncorrelated in the unobserved innovation $w_{i t}$ in other expressions:

$$
E\left(w_{i t} \mid k_{i t}\right)=0
$$

In this case, however, innovation would be related to any decision in the production process that can be made between period $t-1$ and $t$. Such labor input controlled at period $t$ would be correlated within $w_{i t}$. However, the labour lag, $l_{i t-1}$, would not, with that part of a set of the information at time $t-1$. Thus,

$$
E\left(w_{i t} \mid l_{i t-1}\right)=0
$$

The complete set of conditions moment for Equation (8) is therefore yielded by $E\left(U_{i t} \mid k_{i t}, l_{i t-1}, k_{i t-1}, \mathrm{i}_{i t-1}\right)=0$. The undefined functions $f($.$) and g($.$) have thus been proxied$ by the third degree polynomials $[47,51]$. Equation (8) can be evaluated using the instrumental variable estimations with the instrument set $z_{i t=}\left(k_{i t}, l_{i t}, k_{i t-1}, \mathrm{i}_{i t-1}, \ldots\right)$, where all the higher-order terms and their respective interactions with the polynomial act in the same way; all their lags and instruments can 
be used as tests of the instruments in weak identification restrictions. In the evaluation of Equation (8), a complete set of the dummies is involved to control the heterogeneity over time in the PF and productivity. Once again, in line with estimators for $\beta_{l}$ and $\beta_{k}$, the productivity can be estimated in the following form:

$$
\hat{\S}_{i t}=y_{i t}-\hat{\beta}_{l} l_{i t}-\hat{\beta}_{k} k_{i t} \text {. }
$$

\subsection{Productivity Spillover Estimation}

Since our main objective relates to labor productivity, we can convert Equation (11) into a labor-intensive form in the following:

$$
\ln \left(\frac{y_{i t}}{l_{i t}}\right)=\beta_{l} \ln \left(\frac{l_{i t}}{l_{i t}}\right)+\left(\frac{k_{i t}}{l_{i t}}\right)+\sum_{p=1}^{p} Z_{i j t}+i t+\varepsilon_{i t}
$$

where $Z_{i j}$ describes the $j^{\text {th }}$ value of the explanatory variable, which has not been explicitly involved. Previous studies $[25,34]$ have argued that the efficient technology frontier embodied by foreign invested firms influences the productivity and efficiency levels of hosting country firms through spillover effects. Our main objective is to identify whether there is valid evidence for FDI spillovers on the productivity of local firms associated with the direct linkages. To investigate the impact of foreign presence on the local firm productivity following $[10,14]$ and extended from Equation (12), we obtain the following linear PF by adding several explanatory and control variables for the purpose of empirical estimation:

$$
\ln L P_{i j}=\beta_{k} \ln K_{i j}+\beta_{l} \ln L_{i j}+\beta_{M} \ln M_{i j}+\beta_{L Q} L Q_{i j}+\beta_{F S} \ln F S_{i j}+\beta_{y e a r} \ln Y e a r_{i j}+\beta_{C F D I} C F D I_{i t}+{ }_{i t}+\varepsilon_{i j}
$$

where the subscripts $\mathrm{i}$ and $\mathrm{j}$ refer to the firm and sector, respectively. $L P_{i j}$ denotes labor productivity in sector $\mathrm{j}$, and $M_{i j}, L_{i j}$, and $K_{i j}$ refer to production inputs: materials, capital, and labor, respectively. LQ is labor quality, Year is the age of the firm, and FS is the firm scale. CFDI is a dummy variable that represents Chinese firms only, and FDI represents the ratio of Chinese firm presence to local firms. For estimating the productivity spillovers, we constructed the following equation:

$$
\begin{gathered}
\ln L P_{i j}=\beta_{k} \ln K_{i j}+\beta_{l} \ln L_{i j}+\beta_{M} \ln M_{i j}+\beta_{L Q} L Q_{i j}+\beta_{F S} \ln F S_{i j}+\beta_{\text {year }} \ln Y e a r_{i j}+ \\
\beta_{G A P} G A P_{i j}+\beta_{F D I} F D I_{i j}+\S_{i t}+\varepsilon_{i j}
\end{gathered}
$$

where all main and control variables are described in the description section.

\subsection{Description of the Variables}

Measurement of FDI Presence

Given the panel dataset format, the existence of FDI is designed following [10], the share of a foreign firm's output presence being estimated in the intra-industry at the sectoral level (see [13], where the FDI spillovers are calculated at the sector level for Indonesian manufacturers; we adapt the majority of previous studies to calculate FDI at the industrial level):

$$
\mathrm{FDI}_{i j}=\frac{\sum_{\mathrm{i} \in \mathrm{j}} \text { Foreign } \text { output }_{i j}}{\sum_{\mathrm{i} \in \mathrm{j}} \text { Total Output }_{i j}}
$$

where the total output indicates the output of the firm level in a set of sectors, $i \in j$ stands for the firms in the given sector, and Foreign Output denotes the output of the Chinese firms. We made classifications using two-digit values based on the "International Standard Industrial Classification" (ISIC Revision-3.1) codes. However, some sectors were merged together for calculation due to data limitations (see Table 3). As is well known, most of the readers in this particular field would perceive 
immediately that the description of $\mathrm{FDI}_{i j}$ is the standard dimension of the "horizontal effect" in the FDI literature.

We expect all explanatory and control variable coefficients explicitly involved in the regression to be significantly and positively correlated with the dependent variable. The CFDI is represented as a dummy variable that takes 1 if the firm has Chinese majority or minority ownership and 0 otherwise. In addition, we assumed that the CFDI coefficient would obtain a significant and positive correlation, which might imply that the Chinese firms can be more productive than local firms. The other control variables used in this study are described as follows: the firm's age (Year) represents how long a firm has remained in the production in the studied time period. We considered this variable based on the assumption that firms that stay in business longer are a greater benefit and are more efficient in productivity. The firm's scale (FS) variable was measured based on the firm's individual size and the total initial fixed assets, assuming that a more productive firm would be associated with high initial fixed assets.

We further used additional control dummy variables to analyze the effect of domestic firm characteristics on spillover effects, and we used their interaction with the calculated FDI variable to measure the absorptive capacity. The first dummy variable is the technology gap (GAP). Following the literature $[8,13,52]$, we defined relative backwardness based on the technological competency of both Chinese and local firms at the same industry level. When we assumed that local firms have lower productivity than Chinese affiliates and then we calculated the average share of the labor productivity of the Chinese firms in relation to the two-digit sectoral values of a local firm's labor productivity under the same classification. A positive result confirms that domestic firms are less productive than their foreign direct competitor firms. Conversely, for local firms that exerted high labor productivity relative to their direct Chinese competitors, the calculated value of GAP had an inverse result of the former (negative). In other words, a negative value obtained for the GAP indicates a higher productivity in the local firms obtained compared to the Chinese firms.

Afterwards, based on the obtained value, a GAP yields 1 if the value is positive and 0 if the value is negative. In addition, these dummy variables allowed us to identity local firms with high or low absorptive capacity in terms of foreign technology. Moreover, GAP values higher than 1 are signals of large variations in technology among local firms and their foreign direct competitors. On the other hand, large technology gaps might arise if local and foreign firms utilize different technologies (i.e., they are operating on different production isoquants) if they choose very separate factor intensities (within the same isoquant) [52,53].

The other variable was the firm's size, which is related to the total number of employees in a given sector of an individual firm. Firms with $\geq 50$ and $<50$ employees were considered large and small firms, respectively (the classification of small and large firms is different from country to country; accordingly, the CSA of Ethiopia uses a similar categorization, where firms are defined as small (between 10 and 49 employees) or large ( $\geq 50$ employees)). Based on this assumption, we used the dummy variable for representing the variable SIZE, which is 1 or 0 for large or small firms, respectively, and then multiplied by the FDI presence to observe the impact of the SIZE on the spillovers (an alternative system was used to split the sample into small and large firms and to evaluate Equation (14) separately for each group; the result was the same as that reported here).

The labor quality (LQ) variable measured the ratio of total management personnel, engineers, scientists, technicians, and other qualified office workers in each firm to total employment, and was used as a proxy for labor quality (the correlation among wages and labor productivity prevents us from utilizing wage data to proxy LQ). We then multiplied the LQ by the FDI presence effect of the domestic skilled labor on the spillovers. We further investigated the absorptive capacity of the local firm's characteristics. The FDI spillovers may vary among local firms, whether or not they are participating in the export of their product. Thus, following previous literature, a local firm was considered as an exporter when its total export volume was at least $5 \%$ of the annual total sales [8,54]. Thus, we accordingly classified the sample of local firms into two groups and examined them independently. 


\subsection{Data Sources and Summary of Industry Distribution}

The data employed in this study were compiled from various sources. The first data source was the "Report of the Central Statistical Agency (CSA) of Ethiopia, Small Scale Manufacturing Industry, 2017, and Large and Medium Scale Manufacturing Industries Survey" [55-57]. These census data were focused on large-, medium-, and small-scale manufacturing enterprises in Ethiopia for various years. The "Annual Statistical Bulletin of China's Outward Foreign Direct Investment" for various years was used as a secondary additional data source [58,59]. The third data source was Ethiopian Investment Commission (EIC) data covering 1992-2018, collected by requesting it from the office directly by sector and status (unpublished data spread worksheets). The datasets contained detailed information on various variables were used to examine the spillover and classify the firms based on a wide range of indicators, including the date of registration, the name of investor, the country of origin, the type of investment activity, the address of the firm, ownership status, the two- and four-digit industry code, the gross annual output, the initial investment, the export status, total employment, capital stock, employee wages, intermediate material inputs, regions to which the sector distributed, firms on which the sector focused, LQ data, and others. The sectors' dataset was classified based on the ISIC, but we followed the data according to the values of all economic activities from the Central Statistical Agency of Ethiopia ISIC-2, revision 4 [60].

Our samples were reduced to 2554 manufacturing firms due to the absence of some important variables for the study. For the few manufacturing sectors, no Chinese firms were present at the same industry level. Some of the sectors that operated in manufacturing were excluded for several reasons. The first reason was that there were too many missing key variables, and the second reason was that, for the purpose of comparisons Chinese affiliated firms with domestic at the same industry level; we included sectors that have only foreign-affiliated in two-digit classifications. Furthermore, since our study focused mainly on the manufacturing sector, we excluded other industries, such as agriculture, hunting and forestry, mining, quarrying, and other industry classifications. Moreover, observations with missing values and those that fail to satisfy some basic error checks were removed. Hence, after consideration of this information, accordingly the final samples of the study consisted of 2170 domestic and 384 Chinese affiliated firms. It should be noted, that in order to maintain confidentiality, the dataset is not disclosed to prevent firm identifiers.

Table 1 presents a summary of the Chinese firm distribution by ownership on the aggregate level and productivity. As presented in the table, the definitive preference of Chinese investors in the Ethiopian market was majority ownership (349; 91\%), whereas only 35 (9\%) preferred minority ownership. This implied that few Chinese firms were collaborative with domestic and/or other foreign country investors in the form of joint ventures, mergers, and acquisitions. Regarding labor productivity, Chinese firms were more productive than domestic firms in the same sector (Table 1).

Table 1. Summary of Chinese firm distribution by ownership and productivity.

\begin{tabular}{|c|c|c|}
\hline \multirow{2}{*}{ Ownership } & \multicolumn{2}{|c|}{ Chinese Firms } \\
\hline & Number & Percentage \\
\hline Majority & 349 & 90.89 \\
\hline Minority & 35 & 9.11 \\
\hline Total & 384 & 100.00 \\
\hline \multicolumn{3}{|c|}{ Productivity } \\
\hline All firms & Domestic & Chinese \\
\hline $\mathrm{Y} / \mathrm{L}\left(\right.$ mean $\left.^{\mathrm{b}}\right) 3781.75$ & 1177.00 & 2604.75 \\
\hline
\end{tabular}

Note: ${ }^{b}$ in millions of Ethiopian Birr. Source: authors' computations based on the data from the Ethiopian Investment Commission (EIC). 
Table 2 presents the summary of industry distribution by number and size of domestic and Chinese firms. In terms of the number and size distribution, the majority of Chinese firms $(250 ; 65.10 \%)$ were large, and the majority of domestic firms $(1551 ; 71.47 \%)$ were small.

Table 3 illustrates a summary of domestic and Chinese firms classified by sector. Chinese firms showed a greater share in the sectors of textiles and wearing apparel, motor vehicles, trailers and semi-trailers, machinery and equipment, rubber and plastic products, and fabricated metal products. These sectors need massive capital and technology, and Chinese firms have enough resources in capital, technology, knowledge, and information, and are highly efficient. Their entry into the Ethiopian market leads to competition because they improve their products or reduce their prices, and they have exploitative practices of local monopolists.

Table 2. Summary of industry distribution by number and size.

\begin{tabular}{|c|c|c|c|c|c|c|}
\hline \multicolumn{7}{|c|}{ Distribution of Firms } \\
\hline \multirow{2}{*}{ Firm by Size } & \multicolumn{2}{|c|}{ All Firms } & \multicolumn{2}{|c|}{ Domestic } & \multicolumn{2}{|c|}{ Chinese } \\
\hline & Number & Percentage & Number & Percentage & Number & Percentage \\
\hline Large & 799 & 31.28 & 619 & 28.53 & 250 & 65.10 \\
\hline Small & 1755 & 68.72 & 1551 & 71.47 & 134 & 34.90 \\
\hline Total & 2554 & 100.00 & 2170 & 100.00 & 384 & 100.00 \\
\hline
\end{tabular}

Source: authors' computations based on the data from EIC and the Central Statistical Agency (CSA). Note that both small and large domestic firms indicated that $100 \%$ ownership was controlled by domestic investors. Large vs. small firms' classifications were based on the number of employees. We considered firms with $\geq 50$ and 10-49 employees "large" and "small", respectively.

Table 3. Summary of industry distribution of domestic and Chinese firms.

\begin{tabular}{|c|c|c|c|c|c|c|}
\hline \multirow{2}{*}{$\begin{array}{c}\text { 2-Digit } \\
\text { Level }\end{array}$} & \multirow{2}{*}{ Sectors } & \multirow{2}{*}{$\begin{array}{c}\text { All } \\
\text { Firms }\end{array}$} & \multicolumn{2}{|c|}{ Domestic } & \multicolumn{2}{|c|}{ Chinese } \\
\hline & & & Number & $\%$ & Number & $\%$ \\
\hline $15-16$ & Food, Beverages And Tobacco Products & 706 & 687 & 97.31 & 19 & 2.69 \\
\hline $17-18$ & Textiles, Wearing Apparel, Except Fur Apparel & 166 & 77 & 46.39 & 89 & 53.61 \\
\hline 19 & Tanning and Dressing of Leather; Footwear, Luggage and Handbags & 168 & 141 & 83.93 & 27 & 16.07 \\
\hline 20 & Products of Wood and Cork, Except Furniture & 111 & 86 & 77.48 & 25 & 22.52 \\
\hline $21-22$ & Paper Products and Printing & 143 & 122 & 85.31 & 21 & 14.69 \\
\hline 24 & Chemicals and Chemical Products & 101 & 77 & 76.24 & 24 & 23.76 \\
\hline 25 & Rubber and Plastic Products & 145 & 106 & 73.10 & 39 & 26.90 \\
\hline 26 & Other Non-Metallic Mineral Products & 433 & 409 & 94.46 & 24 & 5.54 \\
\hline 27 & Basic Iron and Steel & 47 & 39 & 82.98 & 8 & 17.02 \\
\hline 28 & Fabricated Metal Products Except Machinery and Equipment & 190 & 141 & 74.21 & 49 & 25.79 \\
\hline 29 & Machinery and Equipment & 13 & 6 & 46.15 & 7 & 53.85 \\
\hline 34 & Motor Vehicles, Trailers and Semi-Trailers & 15 & 8 & 53.33 & 7 & 46.67 \\
\hline \multirow[t]{2}{*}{36} & Furniture Manufacturing & 316 & 271 & 85.76 & 45 & 14.24 \\
\hline & Total & 2554 & 2170 & 84.96 & 384 & 15.04 \\
\hline
\end{tabular}

Source: authors' computations based on the data from EIC and CSA.

\section{Empirical Results}

In this section, we first introduce the results of the regression outlined in the methodology section using Equations (13) and (14). For the purpose of estimating, we used 2-digit sector level industry dummies to control the level of productivity between domestic and foreign firms across the industries. For Table 4, the ordinary least squares (OLS) technique was used for a preliminary investigation of labor productivity using Equation (13). However, for Table 5 and onwards, we assume that there might be endogeneity problems for the presence of an FDI spillover variable in the model, and some might be omitted in the specifications, which may be misleading. Therefore, in order to constrain the robustness of the estimation results, we further considered the instrumental variable (IV) specification system of the two-step GMM econometric approach within the models. The reported results of the standard errors for heteroscedasticity were robust in all estimation models. 
Table 4. Impact of Chinese firm ownership on productivity.

\begin{tabular}{ccc}
\hline \multirow{2}{*}{ Dependent Variable: All Firms' Labor Productivity } \\
\hline \multirow{2}{*}{ Independent Variables } & \multicolumn{2}{c}{ OLS } \\
\cline { 2 - 3 } & $\mathbf{( 1 . 1 )}$ & $\mathbf{( 1 . 2 )}$ \\
\hline Constant & $4.44^{* * *}(1.29)$ & $4.29^{* * *}(1.42)$ \\
$\ln (\mathrm{K})$ & $0.76^{* * *}(0.22)$ & $0.75^{* * *}(0.23)$ \\
$\ln (\mathrm{L})$ & $0.87^{* * *}(0.02)$ & $0.86^{* * *}(0.02)$ \\
$\ln (\mathrm{M})$ & $0.15^{* *}(0.12)$ & $0.15^{* *}(0.13)$ \\
LQ & $0.67^{* * *}(0.13)$ & $0.67^{* * *}(0.14)$ \\
$\ln (\mathrm{FS})$ & $0.22^{*}(0.19)$ & $0.22^{*}(0.20)$ \\
$\ln ($ Year) & $0.22^{* * *}(0.15)$ & $0.22^{*}(0.16)$ \\
CFDI & & $0.27^{* *}(0.23)$ \\
\hline R-squared: & 0.96 & 0.96 \\
Observations: & 2554 & 2554 \\
Breusch-Pagan-Godfrey: & $2.98(0.70)$ & $3.61(3.72)$ \\
Jarque-Bera: & $0.72(0.69)$ & $0.55(0.75)$ \\
F-statistic: & $39.54^{* * *}$ & $29.80 * * *$ \\
\hline
\end{tabular}

The values in brackets represent the heteroscedasticity robustness of standard errors. * Significant at the 0.10 level; ** Significant at the 0.05 level; *** Significant at the 0.01 level. OLS: ordinary least squares.

Table 5. Foreign direct investment (FDI) presence and productivity spillover effects on domestic firms.

\begin{tabular}{|c|c|c|c|c|c|c|}
\hline \multicolumn{7}{|c|}{ Dependent Variable: Local Firms' Labor Productivity } \\
\hline \multirow{2}{*}{$\begin{array}{l}\text { Independent } \\
\text { Variables }\end{array}$} & \multicolumn{3}{|c|}{ OLS } & \multicolumn{3}{|c|}{ IV Two-Step GMM } \\
\hline & (1.1) & (1.2) & (1.3) & (1.4) & (1.5) & (1.6) \\
\hline Constant & $\begin{array}{c}0.20 * * * \\
(0.00)\end{array}$ & $\begin{array}{l}0.05^{* *} \\
(0.46)\end{array}$ & $\begin{array}{c}0.14^{* *} \\
(0.12)\end{array}$ & $\begin{array}{c}0.20^{* * *} \\
(0.04)\end{array}$ & $\begin{array}{l}0.04^{* *} \\
(0.42)\end{array}$ & $\begin{array}{l}0.14^{* *} \\
(0.12)\end{array}$ \\
\hline $\ln (\mathrm{K})$ & $\begin{array}{c}0.95^{* * *} \\
(0.00)\end{array}$ & $\begin{array}{c}0.99^{* * * *} \\
(0.01)\end{array}$ & $\begin{array}{c}0.98^{* * *} \\
(0.01)\end{array}$ & $\begin{array}{c}0.96^{* * *} \\
(0.00)\end{array}$ & $\begin{array}{c}1.07^{* * * *} \\
(0.02)\end{array}$ & $\begin{array}{c}0.99^{* * * *} \\
(0.01)\end{array}$ \\
\hline $\ln (\mathrm{L})$ & $\begin{array}{l}0.88^{* * *} \\
(0.02)\end{array}$ & $\begin{array}{c}0.87^{* * * *} \\
(0.02)\end{array}$ & $\begin{array}{c}0.87^{* * * *} \\
(0.03)\end{array}$ & $\begin{array}{c}0.87^{* * *} \\
(0.03)\end{array}$ & $\begin{array}{c}0.85 * * * \\
(0.03)\end{array}$ & $\begin{array}{c}0.79^{* * * *} \\
(0.05)\end{array}$ \\
\hline $\ln (\mathrm{M})$ & $\begin{array}{c}0.06^{* * *} \\
(0.00)\end{array}$ & $\begin{array}{l}0.05^{*} \\
(0.02)\end{array}$ & $\begin{array}{l}0.04 \text { * } \\
(0.02)\end{array}$ & $\begin{array}{c}0.06^{* * *} \\
(0.00)\end{array}$ & $\begin{array}{c}0.05^{* * * *} \\
(0.01)\end{array}$ & $\begin{array}{l}0.04 \text { * } \\
(0.02)\end{array}$ \\
\hline LQ & $\begin{array}{c}0.03^{* * *} \\
(0.00)\end{array}$ & $\begin{array}{l}0.05 * \\
(0.09)\end{array}$ & $\begin{array}{l}0.01 * \\
(0.01)\end{array}$ & $\begin{array}{c}0.03^{* * *} \\
(0.00)\end{array}$ & $\begin{array}{l}0.03 \text { * } \\
(0.08)\end{array}$ & $\begin{array}{l}0.13^{* *} \\
(0.01)\end{array}$ \\
\hline $\ln (\mathrm{FS})$ & $\begin{array}{c}0.97^{* * *} \\
(0.00)\end{array}$ & $\begin{array}{c}0.98^{* * * *} \\
(0.02)\end{array}$ & $\begin{array}{c}0.99 * * * \\
(0.01)\end{array}$ & $\begin{array}{c}0.97^{* * *} \\
(0.00)\end{array}$ & $\begin{array}{c}0.99 * * * \\
(0.02)\end{array}$ & $\begin{array}{c}0.99 * * * * \\
(0.01)\end{array}$ \\
\hline $\ln ($ Year $)$ & $\begin{array}{c}0.07 \\
(0.03)\end{array}$ & $\begin{array}{l}0.01 \text { ** } \\
(0.00)\end{array}$ & $\begin{array}{l}0.02^{* *} \\
(0.00)\end{array}$ & $\begin{array}{c}0.07^{* * *} \\
(0.00)\end{array}$ & $\begin{array}{l}0.02 * \\
(0.01)\end{array}$ & $\begin{array}{l}0.25^{* *} \\
(0.00)\end{array}$ \\
\hline GAP & $\begin{array}{l}0.04^{* *} \\
(0.01)\end{array}$ & $\begin{array}{l}0.06^{* *} \\
(0.02)\end{array}$ & $\begin{array}{c}0.15^{* * *} \\
(0.03)\end{array}$ & $\begin{array}{l}0.04^{* *} \\
(0.01)\end{array}$ & $\begin{array}{l}0.07^{* *} \\
(0.03)\end{array}$ & $\begin{array}{l}0.16^{* *} \\
(0.01)\end{array}$ \\
\hline FDI & $\begin{array}{c}0.27^{* * *} \\
(0.01)\end{array}$ & $\begin{array}{c}1.02 * * * \\
(0.13)\end{array}$ & $\begin{array}{c}1.06^{* * *} \\
(0.02)\end{array}$ & $\begin{array}{c}1.07^{* * *} \\
(0.01)\end{array}$ & $\begin{array}{c}1.08^{* * *} \\
(0.13)\end{array}$ & $\begin{array}{c}1.09^{* * * *} \\
(0.02)\end{array}$ \\
\hline $\mathrm{FDI}^{*} \mathrm{GAP}$ & $\begin{array}{c}-0.15^{* * *} \\
(0.00)\end{array}$ & & & $\begin{array}{c}-1.58^{* * *} \\
(0.31)\end{array}$ & & \\
\hline FDI*LQ & & $\begin{array}{l}0.79 * * \\
(0.01)\end{array}$ & & & $\begin{array}{c}2.85 \\
(0.01)\end{array}$ & \\
\hline $\mathrm{FDI}^{*} \mathrm{SIZE}$ & & & $\begin{array}{c}0.34 \\
(0.36)\end{array}$ & & & $\begin{array}{c}3.43 \\
(0.00)\end{array}$ \\
\hline R-squared: & 0.99 & 0.99 & 0.99 & 0.99 & 0.99 & 0.99 \\
\hline Observations: & 2170 & 2170 & 2170 & 2170 & 2170 & 2170 \\
\hline
\end{tabular}

The values in the brackets represent the heteroscedasticity robustness of standard errors. ${ }^{*}$ Significant at the 0.10 level; ** Significant at the 0.05 level; *** Significant at the 0.01 level. GMM: generalized-method-of-moments.

Our empirical investigation was carried out by estimating the effects of labor productivity. First we estimated the labor productivity separately for the manufacturing sector. Some sectors were combined 
together into two-digit industry level for the purpose of analysis because firms are too small, such as Sectors 15 and 16, Sectors 17 and 18, and Sectors 21 and 22). The whole sample from our dataset was included to estimate labor productivity by assuming that a significant sample size would be more representative and may provide reliable function parameters. The estimated coefficient results are reported in Table 4. To determine the reliability of the regression analysis, tests for the validity of the models were performed using stability test approaches such as the Breusch-Pagan-Godfrey test for heteroscedasticity, Jarque-Bera for normality, and F-statistics, which confirmed that all regression models were valid (Table 4). In addition, the value of R-squared (i.e., 0.96) implies that the control variables in the system represented about $96 \%$ of the total information included in the model estimation. The remaining $4 \%$ of factors might be explained outside the models that were not included. In the first investigated regression result of Equation (13), all sectors labor productivity was normalized as labor-intensive form in the response variable, and other variables were considered on the explanatory variables, except the CFDI control variable for column 1.1 in Table 4.

All the estimated variables' provability values were confirmed as statistically significant and as positive coefficients with respect to the response variable. In other words, the material input $(\ln M)$, labor input $(\operatorname{lnL})$, capital $(\operatorname{lnK})$, labor quality (LQ), the firms' years of experience (lnYear), and the fixed asset of the firm (lnFS) positively impacted the dependent variable. This implies that the panel data regression model designed to investigate labor productivity yielded the expected results. The result obtained from domestic investment implies that achieving better productivity based on the domestic investment ratio can lead to improvements in the country's output growth. Moreover, the result proves that domestic investment still supports economic growth for Ethiopia and helps achieve SDGs, since economic growth reduces poverty and improves income distribution in all countries [2].

To examine the Chinese firms' productivity performance, specifically in Table 4 (column 1.2), we included the dummy variable (CFDI) in the regression to estimate the impact of foreign firm productivity on the country's economic development. The result displays that the coefficient of CFDI positively impacts the dependent variable with a standard significant level of $0.05 \%$ (column 1.2 in Table 4). This finding implies that all things are constant when Chinese firms increase by approximately $10(0.27)=2.7 \%$, and are on average more productive than the Ethiopian firms at the same sector. Moreover, all other independent variables displayed positive coefficients with the standard significant level, as expected. The findings are not surprising since Chinese firms have embedded efficient technology and have better knowledge and skill in the manufacturing sector, so their firms could be more productive than the local firms in the same industry [61]. The results further demonstrate that Chinese firms achieve higher productivity than the domestic firms, which means their presence in Ethiopia is significant for socio-economic development due to the capacity of their investment productivity. There are several possible explanations for how foreign-affiliated firms are more productive than local firms in the same industry. The theoretical and empirical arguments suggest that higher productivity gains from FDI could be generated from superiority in embedded technology, efficiency improvement, advancement in managerial expertise, scale-production knowledge, and technical efficiency, which have not often been available at the same level in domestic firms $[14,61,62]$.

The other objective of our study was to corroborate the extent of local firm productivity and its absorptive capacity, which is associated with the presence of FDI spillover, taking into account both the direct and indirect effects [63]. Thus, to examine these impacts, we used only the domestic firms included in our dataset, and we had all the necessary information for the analysis. The investigation was carried out using Equation (14), and the results are presented in Table 5.

In Table 5, columns 1.1-1.3 are based on the OLS approach, and columns 1.4-1.6 are based on the two-step system of IV GMM approach. In all estimation results, the coefficients of capital (lnK) were lower when the estimation used the OLS approach compared with the two-step system IV GMM method. The result shows that firms' capital selection is positively associated with the productivity, which implies that OLS estimation leads to a downward bias in the lnK coefficient. The coefficient of 
labor was lower in the two-step system IV GMM estimation approach, implying that there is a positive association among productivity and labor, leading to an upward bias in the $\ln L$ coefficient during the OLS approach. This is in line with the assumption that more productive firms hire a low number of laborers per output unit $[7,48]$.

Concerning the FDI spillover variable (FDI) coefficient, results positively impacted the labor productivity with a standard significance level of $0.01 \%$ in all model estimations (Table 5 , columns 1.1-1.6). This implies that local firms gain positive productivity spillovers from the presence of Chinese firms in the manufacturing industry. These externalities, which have been classically referred to as positive productivity spillovers, are supposed as helping to stimulate a comparative advantage for the country economy over time in a sustainable way [62]. These findings further support the idea of [62] that the FDI presence of foreign affiliates supports domestic firms by applying superior technology that imitates the efficiency of productivity, which moves the technological frontier upward in the form of spillovers for socio-economic development improvements [31]. However, the estimation results in the OLS and IV GMM approaches have slightly different coefficients in terms of spillover effects (Table 5). This result further shows the presence of a potential endogeneity problem in the productivity of domestic firms and the presence of FDI in the estimation model. The impact of other explanatory and control variables, i.e., labor quality, capital intensity, the firms' years of experience, material inputs, and the relative firm scale, have a positive, significant impact on all estimations, as expected, and these results do not have a noticeable significant difference which are reported in Table 4.

In the case of the dummy control variables of the local firm's characteristics of the absorptive capacity, the technology gap, the labor quality, and the firm size related to the presence of their foreign encounter are discussed in the following. The term "absorptive capacity", as argued in ([48], p. 23), "includes the ability to internalize knowledge created by others and [modify] it to fit their own specific applications, processes and routines". In our study, we assumed that domestic firms' labor might have knowledge that is different from foreign firms, in order to gain a benefit from the efficient technology from foreign firms. We measured this knowledge difference by labor quality and the proprietary of technology used, which might have significantly determined productivity variances among the low and high absorptive capacities of local firms. Previous studies have argued that efficient technology might not have an automatic direct impact on domestic firms embedded by foreign firms in a given industry. To realize a direct impact, domestic firms should have the basic knowledge to adapt and absorb the efficient technology embedded by foreign firms in the same industry $[8,9,64]$. Hence, technologies implemented by foreign firms could be reliable for local firms, if a moderate GAP difference was detected, where the domestic firms have the basic knowledge needed [53]. When the GAPs become high, the foreign technologies might not be useful for local firms due to the varieties of the product produced through foreign firms that might differ from the local varieties, so the local firm has no technological knowledge to gain from the foreign firms.

Based on the aforementioned premises to investigate the technology gap, we split our sample of 2170 local firms into two sub-groups. When the dummy GAP value was 0,956 local firms were considered to have a slight technology gap compared to Chinese firms, where the labor productivities were not substantially different from the average Chinese affiliated firms in their two-digit industry level. When the dummy GAP value was 1, 1214 firms were considered to have very large technology gaps compared to foreign firms. Column 1.4 of Table 5 shows that the coefficient of the FDI variable has a positive correlation and a significant effect. On the contrary, the interaction coefficient with the parameter $\mathrm{FDI}^{*} \mathrm{GAP}$ has a negative and significant effect on labor productivity at a $1 \%$ significance level of the sub-sample of large technology gaps (Table 5, columns 1.1 and 1.4, respectively). This negative result implies that there is a significant difference between the two groups of samples. It has been confirmed that the Chinese firms had positive spillover effects on the local firms, with the largest absorptive capacity (i.e., facing slight technology gaps). However, the findings further imply that a smaller technology gap from the foreign-affiliated firms may imitate the stronger learning capability and the potential of domestic enterprises, i.e., the capability to absorb and utilize the knowledge 
spillover [61]. Furthermore, it is possible that large domestic firms have increased capacities to absorb knowledge spillovers from FDI firms, as they have more resources (for example, a formal R\&D capacity or more skilled workers) than small domestic firms. However, whether large firms are better equipped with the ability to compete with FDI firms than small firms is less obvious [31]. These positive productivity spillovers obtained from foreign affiliates are also related to the sustainable development of the hosting country [3]. Contrarily, the largest technology gaps of the local firms, (i.e., the low absorptive capacity) suffered negative spillover effects, and they have significant labor productivity, ahead of the average Chinese firms' productivity in the same industry. However, scholars have argued that, with the observed technology gap, domestic enterprises are equipped with more space to learn, replicate, and undertake technology and knowledge transfer. Therefore, the rise of substantial inflows of FDI spillovers may stimulate domestic firms to catch up with the best practice and to extend optimal production scales to improve the country's economic development $[15,61]$.

The LQ variable positively impacts the dependent variable with a standard significant level in all estimations (Table 5, columns 1.1-1.6). However, the estimated coefficient of the interactive term (LQ*FDI) had a positive and statistically significant correlation in the OLS estimation (Table 5, column 1.2), whereas in the IV two-step GMM there was a positive correlation but it was insignificant for productivity (column 1.5, Table 5). This result implies that labor quality had a positive influence on the productivity of domestic firms, while the interaction with FDI spillover did not have a substantial influence on local firm productivity, suggesting no sign of spillover effects. The result further suggested that a certain level of labor quality might be needed as a threshold for the domestic firm in order to adapt and implement the technology that the foreign firms use to advance their productivity for the country's economic development. Our result was in accordance with [11], the authors of which found that no firm's human resources contributed to spillover effects to attract foreign firms. Foreign-affiliated innovation can benefit local expertise, market demand, human capital endowment, cooperation with local firms, and economies of scale and scope, particularly in regard to labor knowledge management. Therefore, domestic firms' labor qualities are required to be equipped with a strong dynamic knowledge capacity for economic development to acquire the foreign technology frontiers embedded by foreign firms in the same industry [61].

Similarly, the dummy control variable of size was proxied as the absorptive capacity for the domestic firms. The coefficient of the FDI in the model has a significant and positive effect on the estimated productivity (Table 5). On the contrary, when the size variable interacts with the FDI (FDI*Size), i.e., for the sample of domestic large firms, there is a positive relation, but there is no significant effect on the estimated productivity (columns 1.3 and 1.6 in Table 5). The result suggests that small domestic firms with FDI enjoyed positive spillover effects on the productivity, whereas large domestic firms did not. This result implies that small domestic firms are more productive than large firms in the local market because the large firms face extra market computation by foreign firms, whereas small firms have less computation with foreign firms due to the nature of their market share computation in the industry. Therefore, based on our results, small domestic firms also make a significant contribution to the country's economic development because the presence of overseas investment activities lead to less competition with large domestic firms. The present finding is consistent with similar investigations that focus on large and small firms' spillover effects from the presence of FDI on a local firm's productivity [11,53].

Concerning the estimated evidence on the firm's market orientation, if local firms export their product to international markets, it might affect the level of technology spillovers in the same industry [6]. Since export-oriented domestic firms potentially perform in foreign markets, they might exercise less competitive burden on foreign firms seeking only domestic market investments [64]. In addition, exporting firms could have better requirements for material inputs, labor quality, and other essential inputs supplied by domestic markets, since they are considered as part of the global source of distribution of product networks. In our analysis, we performed separate regression estimates in each 
group of domestic firms (exporter and non-exporter) using the panel regression models specified in Equation (14). The results are reported in Table 6.

Table 6. Productivity spillovers and market orientation for domestic firms.

\begin{tabular}{|c|c|c|c|c|}
\hline \multicolumn{5}{|c|}{ Dependent Variable: Labor Productivity Domestic Firms } \\
\hline \multirow{3}{*}{$\begin{array}{l}\text { Independent } \\
\text { Variables }\end{array}$} & \multicolumn{2}{|c|}{ OLS } & \multicolumn{2}{|c|}{ IV Two-Step GMM } \\
\hline & Non-Exporters & Exporters & Non-Exporters & Exporters \\
\hline & (1.1) & (1.2) & (1.3) & (1.4) \\
\hline \multirow{2}{*}{ Constant } & 0.71 * & $2.30 * *$ & $0.72 *$ & $2.30 * *$ \\
\hline & $(0.20)$ & $(1.02)$ & $(0.21)$ & $(1.02)$ \\
\hline \multirow{2}{*}{$\ln (\mathrm{K})$} & $0.81^{* * *}$ & $0.34 *$ & $0.80^{* * *}$ & $0.34 * *$ \\
\hline & $(0.02)$ & $(0.15)$ & $(0.03)$ & $(0.15)$ \\
\hline \multirow{2}{*}{$\ln (\mathrm{L})$} & $0.86^{* *}$ & $0.79 * * *$ & $0.84^{* * *}$ & $0.75^{* * *}$ \\
\hline & $(0.02)$ & $(0.11)$ & $(0.02)$ & $(0.31)$ \\
\hline \multirow{2}{*}{$\ln (\mathrm{M})$} & $0.93^{* * *}$ & $0.08^{* *}$ & $0.94^{* * *}$ & $0.14^{* * *}$ \\
\hline & $(0.04)$ & $(0.13)$ & $(0.04)$ & $(0.04)$ \\
\hline \multirow{2}{*}{ LQ } & $0.02 *$ & $0.53^{* * *}$ & $0.02 *$ & $0.53^{* * *}$ \\
\hline & $(0.04)$ & $(0.07)$ & $(0.04)$ & $(0.06)$ \\
\hline \multirow{2}{*}{$\ln (\mathrm{FS})$} & $0.11^{* * *}$ & $0.26^{* * *}$ & 0.11 & $0.27^{* * *}$ \\
\hline & $(0.02)$ & $(0.06)$ & $(0.02)$ & $(0.06)$ \\
\hline \multirow{2}{*}{$\ln$ (Year) } & $0.02 * *$ & $0.12 * *$ & $0.02 * *$ & $0.13^{* * *}$ \\
\hline & $(0.01)$ & $(0.07)$ & $(0.01)$ & $(0.07)$ \\
\hline \multirow{2}{*}{ GAP } & $0.05^{* * *}$ & $0.03^{* *}$ & $0.25^{* * *}$ & $0.14^{* *}$ \\
\hline & $(0.01)$ & $(0.02)$ & $(0.03)$ & $(0.01)$ \\
\hline \multirow{2}{*}{ FDI } & $0.67^{* *}$ & -0.14 & $1.93^{* * *}$ & 0.83 \\
\hline & $(0.04)$ & $(0.04)$ & $(0.05)$ & $(0.13)$ \\
\hline Observations & 1829 & 341 & 1829 & 341 \\
\hline R-squared: & 0.99 & 0.99 & 0.99 & 0.99 \\
\hline $\mathrm{ARCH}(2)$ : & $0.43(0.80)$ & $0.92(0.62)$ & $0.43(0.80)$ & $0.42(0.74)$ \\
\hline Jarque-Bera: & $0.16(0.92)$ & $1.42(0.49)$ & $0.16(0.92)$ & $0.24(0.57)$ \\
\hline
\end{tabular}

The values in the brackets represent the heteroscedasticity robustness of standard errors. ${ }^{*}$ Significant at the 0.10 level; ** Significant at the 0.05 level; ${ }^{* * *}$ Significant at the 0.01 level.

As displayed in Table 6, we also estimated both the OLS and the IV two-step GMM standard approach. The FDI spillover variable had a positive effect with a standard significant level of $0.05 \%$ for non-exporting domestic firms, whereas it had a negative and insignificant impact on the productivity exporting domestic firms (Table 6, columns 1.1 and 1.2, respectively). In fact, the empirical result on the presence of FDI (in column 1.1) shows that, if Chinese firms' presence increases by approximately $10 \%$, non-exporting domestic firms productivity can expect to improve by $6.7 \%$, and inversely exporting firms may decline productivity by $1.4 \%$ (column 1.2). Therefore, the existence of Chinese firms in the same industry had a positive and significant effect on the productivity of non-exporting domestic firms. The results of this study are comparable to the findings of [64], wherein it was shown that exporting domestic firms faced a substantial competitive burden in the international market and that hence, the presence of foreign firms performing in the local market was expected to cause significant additional pressures. In other arguments, the FDI spillover effects would be more evident in the situation for non-exporting local firms.

Overall, in all cases, the coefficient of FDI spillovers was lower when the estimated function used the OLS approach (Table 5). This indicated that the expected FDI spillovers were positively associated with the productivity of domestic firms, suggesting that the OLS estimation would lead to a greater downward bias than the estimation result reported by IV GMM. For instance, the coefficient of the FDI spillover variable (FDI) was 0.27 in column 1.1 in the OLS estimation result, which was lower than 1.07 in the IV GMM two-step estimated results shown in column 1.4. Similar results were obtained for the other column results compared to the OLS and the IV GMM estimation (Table 5). Correspondingly, 
the OLS results for FDI spillovers indicated a greater downward bias than the estimation results reported by IV GMM in all estimations for both exporting and non-exporting domestic firms (Table 6). These results show the possibilities of the endogeneity problem with our estimations.

\subsection{Instrument Validity (IV)}

Given the nature of our datasets various sources, the estimations of FDI spillovers have shown bias when the FDI variable includes cross-industry differences in foreign participation, which was considered as endogenous in the regression model. To solve this problem, we introduced an instrument variable for the FDI variable, considering the overall FDI intensity in our estimations. A problem might arise from the identification of the causality direction between the foreign firm output share and the local firm productivity. It was explained in [8] that foreign firms might be more attracted to a particular sector in a given country due to unobserved characteristics that are associated with the local firm productivity. They further argued that controlling such unobservable impacts on that sector might lead to negative spillover effects, whereas not controlling for the target of specific sector impacts could reverse these effects. Therefore, to adequately control these effects in our analysis, we incorporated targeted sector priority effects analysis suggested by [54,65].

Accordingly, if the Chinese firms investing in Ethiopia were attracted to specific industrial sectors that have already experienced higher productivity, the coefficient estimated with respect to the FDI spillovers might show an upward bias. If the firms attracted to or concentrated in the specific sectors have lower productivity, then the coefficient of the estimated FDI spillover might cause a downward spillover bias. To overcome this, an alternative method to address the endogenous problem has been made using the FDI variable. Thus, the endogenous concern was addressed sufficiently by employing a two-step system IV (GMM-2-step-IV) method for Tables 5 and 6. Previously, several studies have applied instruments to solve the possible endogeneity problem related to the presence of FDI and local firm productivity. For instance, the authors of [66] instrument the sectoral presence of the FDI variable in the UK and the incoming sectoral FDI variable from the US. Similarly, in [67], the Mexican manufacturing firms utilize the US sectoral foreign employment share in an instrument for measuring the sectoral FDI spillover. Furthermore, in [54], a study on the FDI spillovers in developing countries, sector targeting was used as an instrumental variable for the presence of FDI. In the current study, following the earlier studies reported by $[8,54,65]$, we instrumented our FDI spillover variable with priority areas (sector targeting) of sectoral extent by the EIC.

Afterwards, we established two instrumental variables: (i) we considered a variable indicating the targeted sector TSC, which takes a dummy variable 1 if the sector $\mathrm{j}$ has been given priority for FDI by EIC for several years, and takes 0 otherwise. (ii) Since our FDI variable indicates the presence of Chinese firms for several years, the other indicator was constructed through an aggregate of dummies between 2012 and 2018 traced back for continuous variables: the Years of Sector Targeting (YSCT) indicated the number of years that the EIC has treated sector $j$ for priority areas for FDI. The sum might be different, ranging from 0 (if the sector does not have given targeting for years) to 6 (including all sums of the targeted year). To handle non-linearity, we included Year of Sector Targeting in logarithm form (by adding 1 before using the log) if the sector has priority for foreign investors. There are several motivations to choose these variables as an instrument. First, we assumed that this instrumental variable would be correlated with the FDI presence and could be uncorrelated with the local firm productivity. It is probable to say that the Government of Ethiopia GoE is selective in allowing FDI in some sectors, which are more or less productive than others. If so, our instruments may have possible biases because the exclusion restriction will probably not be satisfied. However, due to data limitation, we are not able to fully address this issue in the current paper. Therefore, the sector priority areas of the manufacturing firms set by the EIC were considered more appropriate as the instrument, since they were more likely to be suitable for both of the earlier assumptions.

Second, the Government of Ethiopia (GoE) has introduced a five-year Growth and Transformation Plan (GTP I and II; 2010-2015 and 2015-2020, respectively), incorporating several objectives. One of 
the main objectives of the GTPs emphasizes the pillars of the development of the manufacturing sector that play a prominent role in ensuring sustainable growth in the country [68]. The target of the plan was to help Ethiopia to become the leading hub in the manufacturing sector in Africa, thereby transforming the country into a middle-income economy by 2025 [21]. Subsequently, aiming at the sector of manufacturing (the manufacturing sector has a significant impact, but faces binding constraints related to access to land, infrastructure, trade logistics, customs regulations, and a skills gap), the GoE prioritized the incoming FDI (FDI is seen as a way of lifting all these constraints, with an important role to be played in the manufacturing sector and the development of industrial parks) in particular sectors for the set of investment priorities. These sectors were textile and apparel, agro-processing, leather and leather products, pharmaceuticals and chemicals, and metal and engineering [68]. These sectors for the FDI were expected to generate benefits, such as creating labor-intensive jobs, increasing export of products, and utilizing the comparative advantage of the country. Ethiopia has several latent advantages, such as producing leather and leather products, since the country produces a higher quality and quantity of raw leather materials and has a relatively low-cost labor force. Ethiopia also has the second largest population (102.4 million in 2016) in Africa, which leads to cheap and plentiful labor and a sustainable growing economy, on average 10.6\% annually [21]). It is argued in [65] that targeting a specific sector by investment promotion has led to an improved (more than double) incoming FDI in those sectors.

\subsection{Results}

The earlier reported results of the OLS and IV two-step GMM estimations suggest the existence of positive FDI spillovers. However, there are issues in the findings presented in Tables 5 and 6, i.e., the estimated results of the FDI spillover were biased when this variable was considered as endogenous in the estimation model. Therefore, the estimated reports lack required standard properties, specifically consistency and unbiasedness. Thus, as discussed in the instrumental validity section previously, using the year of sector targeting (YSCT) variables as instruments, we re-evaluated our previous regression models by employing the first-stage IV estimation technique on both sub-samples of firms.

The first stage estimation results corresponding to the IV related to Table 5, columns 1.4-1.6, are presented in Table 7, whereas Table 8 presents the first stage results corresponding to Table 6, columns 1.3-1.4. The results of the coefficient of YSCT of the IV and the corresponding interaction control variables showed a statistically significant effect associated with the FDI spillover variable. In addition, the result of the F-statistics in the first stage was significantly higher than the standard critical value of 10, and the weak identification instrument test of Kleibergen-Paap Wald rk F- statistics exceeded the critical value of 7.04. Hence, we rejected the null hypothesis of the weak instrument, so the result further confirmed the reliability and validity of the designed instruments in our analysis.

Similarly, the estimated coefficients of the YSCT for the validity of an exporting or non- exporting firm's instrumental results corresponding to Table 6 (columns 1.3 and 1.4) are statistically significant in relation to the standard significance level, and our instruments were not weak due to the fact that the F-statistics result of the first stage was considerably higher than the standard critical value of 10 (Table 8).

Overall, these results reveal that the spillover effects estimated using the first-stage IV approach were similar to those of the previous IV two-step GMM estimation techniques presented in Table 5, columns 1.4-1.6, and Table 6, columns 1.3-1.4, where both estimation techniques were observed to exert a significant effect on productivity spillover. Therefore, the results presented in Tables 7 and 8 show the robustness of earlier spillover estimates. Furthermore, no noticeable parameter estimated differences in the rest of the variables in the regression model were observed. 
Table 7. First-stage IV estimates corresponding to Table 5.

\begin{tabular}{|c|c|c|c|c|c|c|}
\hline \multirow{2}{*}{$\begin{array}{l}\text { Independent } \\
\text { Variable }\end{array}$} & \multicolumn{2}{|c|}{ (1.4) } & \multicolumn{2}{|c|}{ (1.5) } & \multicolumn{2}{|c|}{ (1.6) } \\
\hline & FDI & FDI $*$ GAP & FDI & FDI ${ }^{*} \mathrm{LQ}$ & FDI & FDI * Size \\
\hline YSCT & $\begin{array}{c}0.63^{* * *} \\
(0.35)\end{array}$ & $\begin{array}{c}0.22 * * * \\
(0.58)\end{array}$ & $\begin{array}{c}0.64^{* * *} \\
(0.28)\end{array}$ & $\begin{array}{c}-0.46^{* * *} \\
(0.03)\end{array}$ & $\begin{array}{l}0.10 * * \\
(0.26)\end{array}$ & $\begin{array}{c}0.28 \\
(0.07)\end{array}$ \\
\hline $\mathrm{YSCT} * \mathrm{GAP}$ & $\begin{array}{c}0.06^{* * *} \\
(0.05)\end{array}$ & $\begin{array}{l}0.03^{* *} \\
(0.02)\end{array}$ & & & & \\
\hline $\mathrm{YSCT}^{*} \mathrm{LQ}$ & & & $\begin{array}{c}-0.03^{* *} \\
(0.06)\end{array}$ & $\begin{array}{l}0.06^{*} \\
(0.03)\end{array}$ & & \\
\hline YSCT * SIZE & & & & & $\begin{array}{c}-0.03^{* *} \\
(0.12)\end{array}$ & $\begin{array}{l}0.03 \text { ** } \\
(0.07)\end{array}$ \\
\hline R-squared & 0.97 & 0.84 & 0.97 & 0.97 & 0.84 & 0.84 \\
\hline F-statistic & 34.00 & 22.17 & 14.76 & 16.07 & 14.54 & 11.44 \\
\hline K.P Wald F-test & 73.12 & & 86.66 & & 84.43 & \\
\hline Observations & 2170 & 2170 & 2170 & 2170 & 2170 & 2170 \\
\hline
\end{tabular}

The regression was run and included all explanatory variables reported in Table 5, but only those efficiency shifts in the coefficients for the instruments are shown for simplicity and in order to save space. Figures in brackets indicate heteroscedasticity robust standard errors. * Significant at the 0.10 level; ** Significant at the 0.05 level; ${ }^{* * *}$ Significant at the 0.01 level.

Table 8. First-stage IV estimates corresponding to Table 6.

\begin{tabular}{ccc}
\hline \multirow{2}{*}{ Independent Variable } & $\mathbf{( 1 . 3 )}$ & $\mathbf{( 1 . 4 )}$ \\
\cline { 2 - 3 } & FDI & FDI \\
\hline YSCT & $0.31^{* *}(0.03)$ & $0.56^{* *}(0.29)$ \\
\hline R-squared & 0.95 & 0.89 \\
F test & 22.17 & 15.15 \\
Observations & 1829 & 341
\end{tabular}

The regressions were run and included all explanatory variables reported in Table 6, but only those efficiency shifts in the coefficients for the instruments are shown for simplicity and to save space. Figures in brackets indicate the heteroscedasticity robust standard errors. * Significant at the 0.10 level; ** Significant at the 0.05 level; *** Significant at the 0.01 level.

\section{Conclusions}

In 2015, the UNGA has come up with a global paradigm agenda of resolution to achieve the SDGs by 2030. Due to specific challenges of funding gaps and a lack of advanced technology, the majority of SSA countries are still behind the standard of world development. Since FDI has the potential to bring needed capital and efficient technology, FDI has often been considered as a vigorous source of development, even for the sustainable development of under-developing economies such as Ethiopia. Hence, the study has explored the effects of intra-industry spillovers from the FDI on the productivity of Ethiopian firms and their relation to Chinese firms. The spillover effects from the FDI on the host economies that improve their productive proficiencies were challenging and sensitive investigation issues. Although overall positive spillover effects have been documented in the previous empirical literature under various conditions in many countries, showing contributions to the country's socio-economic development, the heterogeneous nature of the countries, the technology gap, the labor quality, the firms' market structure, the firms' size, and the ownership structure in the manufacturing sector in Ethiopia that includes Chinese firms had not been investigated. Our investigation was carried out using 2554 Ethiopian and Chinese manufacturing firms operating in Ethiopia. We employed the OLS and the IV GMM two-step techniques to address the possible endogeneity problem. Overall, our result suggested that an increasing investment of Chinese firms has positively correlated with the efficiency of productivity. Specifically, Chinese firms were more than twice as productive compared with Ethiopian firms in the same industry. Thus, Chinese firms operating in Ethiopia had higher productivity levels in the country's manufacturing sector due to the 
superior productive technology implemented and superior managerial abilities, which might lead to greater efficiencies. Thus, the productivity of Chinese firms could have a direct impact, improving income and reducing the country's poverty, which supports the SDGs.

In terms of the characteristics of the domestic firms, overall, our empirical findings show solid evidence that Chinese firms in Ethiopia provided beneficial spillover effects for locals, but these spillover effects depend on the local firm's characteristics. Thus, it was confirmed that local firms gained significant positive spillovers when they had high absorptive capacity, whereas low absorptive capacity firms suffered negative spillover effects. We also found that non-exporting domestic firms increased their productivity by about $0.67 \%$ at a $0.01 \%$ significant level; thus, significant positive spillover effects were obtained from Chinese firms. Concerning the policy implications, the findings of this study clearly demonstrated that SSA countries such as Ethiopia should consider policy prescriptions that attract more FDI and that boost domestic firm productivity and thus support the county's economic development and therefore, through the industrialization process, SDGs. The majority of SSA countries have lacked clear and coherent policies for firms with a dynamic economic partner such as China. This implies such firms might not take full advantage of China's investment in the region to achieve economic development. Chinese policymakers should also encourage more Chinese manufacturing enterprises to invest in SSA countries such as Ethiopia due to the fact that Chinese firms are more productive than local firms.

This study was limited to Ethiopia due to the scarcity of data on other countries. Therefore, future studies can extend our current econometric studies by investigating inter-industry (vertical) spillover by including more appropriate uncontrolled variables and more disaggregated datasets.

Author Contributions: E.S.N. and Z.W. conceived the original idea for the study and designed the methodology; E.S.N., W.Z., and Y.L. analyzed the data; E.S.N. wrote the paper, which was revised by all authors, who each read and approved the final manuscript. All authors have read and agreed to the published version of the manuscript.

Funding: Supported by the Project of Key Discipline in Political Economy from the "Double-First Class" Initiative at Zhejiang University.

Acknowledgments: The authors thank the editor and the three anonymous reviewers for their constructive comments, suggestions, and help in enhancing the manuscript.

Conflicts of Interest: The authors declare that there is no conflict of interest.

\section{References}

1. UNDPC. Report on the Sustainable Development of Chinese Enterprises Overseas; UNDP: Beijing, China, 2017.

2. Suehrer, J. The Future of FDI: Achieving the Sustainable Development Goals 2030 through Impact Investment. Glob. Policy 2019, 10, 413-415. [CrossRef]

3. Kardos, M. The Relevance of Foreign Direct Investment for Sustainable Development. Empirical Evidence from European Union. Procedia Econ. Financ. 2014, 15, 1349-1354. [CrossRef]

4. Ma, D.; Lei, C.; Ullah, F.; Ullah, R. China's One Belt and One Road Initiative and Outward Chinese Foreign Direct Investment in Europe. Sustainability 2019, 11, 7055. [CrossRef]

5. Ridzuan, A.R.; Ismail, N.A.; Hamat, A.F.C. Does foreign direct investment successfully lead to sustainable development in Singapore? Economies 2017, 5, 29. [CrossRef]

6. Liang, F.H. Does foreign direct investment improve the productivity of domestic firms? Technology spillovers, industry linkages, and firm capabilities. Res. Policy 2017, 46, 138-159. [CrossRef]

7. Newman, C.; Rand, J.; Talbot, T.; Tarp, F. Technology transfers, foreign investment and productivity spillovers. Eur. Econ. Rev. 2015, 76, 168-187. [CrossRef]

8. Farole, T.; Winkler, D. Foreign Firm Characteristics, Absorptive Capacity and the Institutional Framework the Role of Mediating Factors for FDI Spillovers in Low- and Middle-Income Countries; Policy Research Working Paper 6265; 2012; Available online: https://papers.ssrn.com/sol3/papers.cfm?abstract_id=2175446 (accessed on 26 September 2019).

9. Javorcik, B.S. Does Foreign Direct Investment Increase the Productivity of Domestic Firms? In Search of Spillovers Through Backward Linkages. Am. Econ. Rev. 2004, 94, 605-627. [CrossRef] 
10. Jeon, Y.; Park, B.I.; Ghauri, P.N. Foreign direct investment spillover effects in China: Are they different across industries with different technological levels? China Econ. Rev. 2013, 26, 105-117. [CrossRef]

11. Sinani, E.; Meyer, K.E. Spillovers of technology transfer from FDI: The case of Estonia. J. Comp. Econ. 2004, 32, 445-466. [CrossRef]

12. Barrios, S.; Strobl, E. Foreign Direct Investment and Productivity Spillovers: Evidence from the Spanish Experience. Rev. World Econ. 2002, 138, 459-481. [CrossRef]

13. Blalock, G.; Gertler, P.J. How firm capabilities affect who benefits from foreign technology. J. Dev. Econ. 2009, 90, 192-199. [CrossRef]

14. Javorcik, B.S.; Spatareanu, M. Does it matter where you come from? Vertical spillovers from foreign direct investment and the origin of investors. J. Dev. Econ. 2011, 96, 126-138. [CrossRef]

15. Le, H.Q.; Pomfret, R. Technology spillovers from foreign direct investment in Vietnam: Horizontal or vertical spillovers? J. Asia Pac. Econ. 2011, 16, 183-201. [CrossRef]

16. Giroud, A.; Jindra, B.; Marek, P. Heterogeneous FDI in Transition Economies-A Novel Approach to Assess the Developmental Impact of Backward Linkages. World Dev. 2012, 40, 2206-2220. [CrossRef]

17. Görg, H.; Greenaway, D. Much ado about nothing? Do domestic firms really benefit from foreign direct investment? World Bank Res. Obs. 2004, 19, 171-197. [CrossRef]

18. Görg, H.; Strobl, E. Multinational Companies And Productivity Spillovers: A Meta-Analysis. Econ. J. 2001, 111, F723-F739. [CrossRef]

19. Smeets, R. Collecting the pieces of the FDI knowledge spillovers puzzle. World Bank Res. Obs. 2008, 23, 107-138. [CrossRef]

20. Tadesse, D. An Analysis of Chinese Foreign Direct Investment (FDI) in Sub-Saharan Africa: A Particular Focus on Ethiopia. Ethiop. J. Bus. Econ. 2015, 4, 183. [CrossRef]

21. Zhang, X.; Tezera, D.; Zou, C.; Wang, Z.; Zhao, J.; Gebremenfas, E.; Dhavle, J. Industrial Park Development In Ethiopia Case Study Report. Inclusive and Sustainable Industrial Development Working Paper Series WP 21/2018. WP 21/2018. Available online: https://www.unido.org/api/opentext/documents/download/10694802/unidofile-10694802 (accessed on 15 November 2019).

22. Megbowon, E.; Mlambo, C.; Adekunle, B. Impact of china's outward fdi on sub-saharan africa's industrialization: Evidence from 26 countries. Cogent Econ. Financ. 2019, 7, 1-14. [CrossRef]

23. Zhou, C.; Hong, J.; Wu, Y.; Marinova, D. Outward foreign direct investment and domestic innovation performance: Evidence from China. Technol. Anal. Strateg. Manag. 2018, 31, 81-95. [CrossRef]

24. Blalock, G.; Gertler, P.J. Welfare gains from Foreign Direct Investment through technology transfer to local suppliers. J. Int. Econ. 2008, 74, 402-421. [CrossRef]

25. Bwalya, S.M. Foreign direct investment and technology spillovers: Evidence from panel data analysis of manufacturing firms in Zambia. J. Dev. Econ. 2006, 81, 514-526. [CrossRef]

26. Kugler, M. Spillovers from foreign direct investment: Within or between industries? J. Dev. Econ. 2006, 80, 444-477. [CrossRef]

27. Barrios, S.; Gorg, H.; Strobl, E. Spillovers through backward linkages from multinationals: Measurement matters! Eur. Econ. Rev. 2011, 55, 862-875. [CrossRef]

28. Damijan, P.; Rojec, M.; Majcen, B.; Knell, M. Impact of firm heterogeneity on direct and spillover effects of FDI: Micro-evidence from ten transition countries. J. Comp. Econ. 2013, 41, 895-922. [CrossRef]

29. Malikane, C.; Chitambara, P. Foreign direct investment, productivity and the technology gap in African economies. J. Afr. Trade 2018, 4, 61-74. [CrossRef]

30. Wang, B.; Gao, K. Forty Years Development of China's Outward Foreign Direct Investment: Retrospect and the Challenges Ahead. China World Econ. 2019, 27, 1-24. [CrossRef]

31. Xu, X.; Yu, S. Productivity Spillovers from Foreign Direct Investment: Firm-Level Evidence from China. World Dev. 2012, 40, 62-74. [CrossRef]

32. Lin, P.; Liu, Z.; Zhang, Y. Do Chinese domestic fi rms bene fi t from FDI in flow? Evidence of horizontal and vertical spillovers. China Econ. Rev. 2009, 20, 677-691. [CrossRef]

33. Girma, S.; Gong, Y.; Görg, H.; Lancheros, S. Estimating direct and indirect effects of foreign direct investment on firm productivity in the presence of interactions between firms. J. Int. Econ. 2015, 95, 157-169. [CrossRef]

34. Masron, T.A.; Zulkafli, A.H.; Ibrahim, H. Spillover Effects of FDI within Manufacturing Sector in Malaysia. Procedia-Soc. Behav. Sci. 2012, 58, 1204-1211. [CrossRef] 
35. Gorodnichenko, Y.; Svejnar, J.; Terrell, K. When does FDI have positive spillovers? Evidence from 17 transition market economies. J. Comp. Econ. 2014, 42, 954-969. [CrossRef]

36. Anwar, S.; Nguyen, L.P. Foreign direct investment and export spillovers: Evidence from Vietnam. Int. Bus. Rev. 2011, 20, 177-193. [CrossRef]

37. Busse, M.; Erdogan, C.; Mühlen, H. China's Impact on Africa-The Role of Trade, FDI and Aid. Kyklos 2016, 69, 228-262. [CrossRef]

38. Kolstad, I.; Wiig, A. Better the Devil You Know? Chinese Foreign Direct Investment in Africa. J. Afr. Bus. 2011, 12, 31-50. [CrossRef]

39. Cheung, Y.W.; De Haan, J.; Qian, X.; Yu, S. China's Outward Direct Investment in Africa. Rev. Int. Econ. 2012, 20, 201-220. [CrossRef]

40. Sanfilippo, M. Chinese FDI to Africa: What Is the Nexus with Foreign Economic Cooperation? Afr. Dev. Rev. 2010, 22, 599-614. [CrossRef]

41. Mourao, P.R. What is China seeking from Africa? An analysis of the economic and political determinants of Chinese Outward Foreign Direct Investment based on Stochastic Frontier Models. China Econ. Rev. 2018, 48, 258-268. [CrossRef]

42. Liu, Y.; Ge, Y.; Hu, Z.; Wang, S. Culture and capital flows-Exploring the spatial differentiation of China's OFDI. China Econ. Rev. 2018, 48, 27-45. [CrossRef]

43. Chen, H.; Pan, J.; Xiao, W. Chinese OFDI and Industrial Upgrading: From the Perspective of the Differences among Countries. China World Econ. 2019, in press. [CrossRef]

44. Weisbrod, A.; Whalley, J. The Contribution of Chinese FDI to Africa' S Pre Crisis Growth Surge. Nber Work. Pap. Ser. 2011. Available online: http://www.nber.org/papers/w17544 (accessed on 9 December 2019).

45. Doku, I.; Akuma, J.; Owusu-Afriyie, J. Effect of Chinese foreign direct investment on economic growth in Africa. J. Chin. Econ. Foreign Trade Stud. 2014, 1, 2-13. [CrossRef]

46. Zhang, J.; Alon, I.; Chen, Y. Does Chinese investment affect Sub-Saharan African growth? Int. J. Emerg. Mark. 2014, 9, 257-275. [CrossRef]

47. Olley, G.S.; Pakes, A. The Dynamics of Productivity in the Telecommunications Equipment Industry. Econometrica 1996, 64, 1263. [CrossRef]

48. Ackerberg, D.; Caves, K.; Frazer, G. Structural Identification of Production Functions. Ariel 2006, 12, 1-35.

49. Levinsohn, J.; Petrin, A. Estimating production functions using inputs to control for unobservables. Rev. Econ. Stud. 2003, 70, 317-341. [CrossRef]

50. Tran, K.C.; Tsionas, E.G. GMM estimation of stochastic frontier model with endogenous regressors. Econ. Lett. 2013, 118, 233-236. [CrossRef]

51. Wooldridge, J.M. On estimating firm-level production functions using proxy variables to control for unobservables. Econ. Lett. 2009, 104, 112-114. [CrossRef]

52. Kokko, A.; Tansini, R.; Zejan, M.C. Local technological capability and productivity spillovers from FDI in the Uruguayan manufacturing sector. J. Dev. Stud. 1996, 32, 602-611. [CrossRef]

53. Dimelis, S.; Louri, H. Foreign Direct Investment and Technology Spillovers: Which Firms Really Benefit? Rev. World Econ. 2004, 140, 231-253. [CrossRef]

54. Harding, T.; Javorcik, B.S. Foreign direct investment and export upgrading. Rev. Econ. Stat. Novemb. 2012, 94, 964-980. [CrossRef]

55. CSA. Large and Medium Scale Manufacturing and Electricity Industries Survey Study Documentation Metadata Production; Centeral statistical Agency: Addis Ababa, Ethiopia, 2015.

56. CSA. Report on Large and Medium Scale Manufacturing and Electricity Industries Survey; The Federal Democratic Republic of Ethiopia Central Statistical Agency: Addis Ababa, Ethiopia, 2012.

57. CSA. Report on Large and Medium Scale Manufacturing; The Federal Democratic Republic of Ethiopia Central Statistical Agency: Addis Ababa, Ethiopia, 2017.

58. MOFCOM. Statistical Bulletin of China's Outward Foreign Direct Investment; MOFCOM: Beijing, China, 2017.

59. MOFCOM. Statistical Bulletin of China's Outbound Foreign Direct Investment; MOFCOM: Beijing, China, 2010.

60. CSA. International Standard Industrial Classification of All Economic Activities Revision 4; Central Statistical Agency: Addis Ababa, Ethiopia, 2012.

61. Hong, J.; Zhou, C.; Wu, Y.; Wang, R.; Marinova, D. Technology Gap, Reverse Technology Spillover and Domestic Innovation Performance in Outward Foreign Direct Investment: Evidence from China. China World Econ. 2019, 27, 1-23. [CrossRef] 
62. Sari, D.W.; Khalifah, N.A.; Suyanto, S. The spillover effects of foreign direct investment on the firms' productivity performances. J. Product. Anal. 2016, 46, 199-233. [CrossRef]

63. Narula, R.; Marin, A. FDI spillovers, absorptive capacities and human capital development: Evidence from Argentina. MERIT Maastricht Econ. Res. Inst. Innov. Technol. 2003, 016, 1-51.

64. Crespo, N.; Fontoura, M.P. Determinant Factors of FDI Spillovers-What Do We Really Know? World Dev. 2007, 35, 410-425. [CrossRef]

65. Harding, T.; Javorcik, B.S. Roll out the Red Carpet and They Will Come: Investment Promotion and FDI Inflows. Econ. J. 2011, 121, 1-41. [CrossRef]

66. Haskel, J.E.; Pereira, S.C.; Slaughter, M.J.; Haskel, E.; Pereira, S.C.; Slaughter, J. Does Inward Foreign Direct Investment Boost the Productivity of Domestic Firms? Rev. Econ. Stat. 2007, 89, 482-496. [CrossRef]

67. Jordaan, J.A. Cross-sectional estimation of FDI spillovers when FDI is endogenous: OLS and IV estimates for Mexican manufacturing industries. Appl. Econ. 2011, 6846, 2451-2463. [CrossRef]

68. GTPII. Growth and Transformation Plan II (GTP II) (2015/16-2019/20), Volume I: Main Text. Ethiopia. 2016. Available online: https:/www.undp.org/content/dam/dagethiopia/documents/gtp_ii_policy_matrix_english_ final_august_2016.pdf (accessed on 5 October 2019).

(C) 2020 by the authors. Licensee MDPI, Basel, Switzerland. This article is an open access article distributed under the terms and conditions of the Creative Commons Attribution (CC BY) license (http://creativecommons.org/licenses/by/4.0/). 